\title{
Factors Affecting the Plasma Prolactin Level in the Cow and the Goat as Determined by Radioimmunoassay
}

\author{
TETSU JOHKE \\ Department of Animal Physiology, National Institute of Animal Industry, \\ Aoba-cho, Chiba-shi
}

Synopsis

Plasma prolactin concentration of serial blood samples taken from cows and goats bearing indwelling jugular venous catheter was assayed by a radioimmunologic procedure. Using 9 lactating cows, the response of prolactin release to milking was investigated at different stages of lactation. In all cases, plasma prolactin levels rapidly increased and reached a peak 4-20 min after the start of milking. The magnitude of the response was considerably different with the stage of lactation in the same cow. The peak of plasma prolactin released by milking was highest in the early stage of lactation (189 $\pm 34 \mathrm{ng} / \mathrm{ml}, \mathrm{SE}$ ), and decreased thereafter with the advance of lactation. Conspicuous response of prolactin release with a 40 - to 100 - fold increase by milking was also obtained in the lactating goats. Feeding could induce a rapid elevation of plasma prolactin in the lactating cow. Mimic- or sham-milking in heifers and in virgin goats in which teats were pulled and the udder was massaged by hands for $5 \mathrm{~min}$, induced an acute prolactin release within 2 min after the start of stimulation, although there was no milk flow. Stressful stimulus associated with venipuncture also elevated the plasma prolactin in the lactating and non-lactating animals. These findings lead to the conclusion that prolactin is a hormone which can be released by various stimuli and that milking is the most powerful of the stimuli for the acute prolactin discharge from the anterior pituitary gland in the cow as well as in the goat at least in the early stage of lactation. At the same time, a variety of non-specific stimuli can also cause a rapid rise in plasma prolactin concentration.

With the successful application of the radioimmunoassay to prolactin, it has previously been demonstrated that the stimuli associated with milking cause an acute prolactin release in the lactating cow and goat (Johke, 1969a). Using one goat, Bryant and Greenwood (1968) also found a rapid rise of plasma prolactin level by milking. The study of plasma prolactin levels in the goat and the cow near parturition suggested that a conspicuous and continuous prolactin release occur for 1-2 days before parturition (Johke et al., 1969 and 1971). In postpartum, the plasma prolactin level of the goat nursing their kids was maintained at high levels by recurrent suckling stimuli, however, it fell rapidly after weaning ( Johke et al., 1969 and 1971).

Received for publication November 18, 1970.
In the present study, the effects of various stimuli including milking at different stages of lactation, mimic-milking or sham-milking, feeding, oxytocin administration and stressful stimuli associated with needle puncture upon the prolactin level in the bovine plasma were investigated. In addition, the effects of milking and mimic-milking on prolactin secretion of goats were also assessed.

\section{Materials and Methods}

\section{Experimental animals}

Cattle: Nine Holstein cows from our Institute's dairy herd calved during March and July, 1968 and 1969 , were used for the experiment of the prolactin release by milking at different stages of lactation. Their body weights ranged between 550 and $630 \mathrm{~kg}$. 
They were milked twice a day by machine milking. Washing the udder with warm water and foremilking were carried out within $2 \mathrm{~min}$ before the start of milking. The cows were usually fed immediately before the start of milking. In the early stage of lactation, some cows were fed $10-30 \mathrm{~min}$ before milking. The duration of milking was inclusive of the time of machine milking and that of hand stripping. Two to $3 \mathrm{hr}$ after milking, other stimuli, i. e., feeding and administration of hormone etc. were given to the cows. The experiment was carried out on a stall platform in a stanchion barn. For the experiment of mimic-milking, 3 heifers of 14 months old weighing $320-370 \mathrm{~kg}$, and 3 cows of 4 years old weighing $600-620 \mathrm{~kg}$ were used. None of them had been pregnant or lactating. The experiments of mimic-milking were done at a restraining stall.

Goat: Five Saanen goats, kidded during May and July in 1969 were milked by hands once a day in a pen at the mid-lactation stage. Their body weights were $55-65 \mathrm{~kg}$. Two virgin Saanen goats of 2 years old were used for the experiment of mimic-milking.

\section{Blood samples and sampling method}

In order to minimize the effect of stress associated with the blood sampling and to get serial samples, the blood of the experimental animals was taken from an indwelling polyethylene catheter inserted into one of the external jugular veins at least $1 \mathrm{hr}$ before the start of the experiment by venipuncure with a bleeding needle (Johke, 1969a). During blood sampling by this method, the animals were quiet and no interruption of rumination or feeding was observed. Serial blood samples (4-7 $\mathrm{m} l$ in each time), were collected into a centrifuge tube containing heparin at 1 to $20 \mathrm{~min}$ intervals and were chilled with ice immediately. At the end of each experiment the blood was centrifuged and the plasma was stored at $-20^{\circ} \mathrm{C}$ until assayed.

\section{Radioimmunoassay}

Plasma prolactin levels in the experimental animals were determined by a radioimmunoassay using two antibody method (Johke, 1969 b). Bovine prolactin (NIH-P-B2) was used as the standard hormone in the assay for prolactin in the cow plasma. Ovine prolactin (NIH-P-S8) was used as the standard hormone in the assay for prolactin in the goat plasma.

\section{Results}

Effect of the stages of lactation upon the response of prolactin release to milking stimulus

Using 9 lactating cows, a total of 28 experiments of the response of prolactin release by

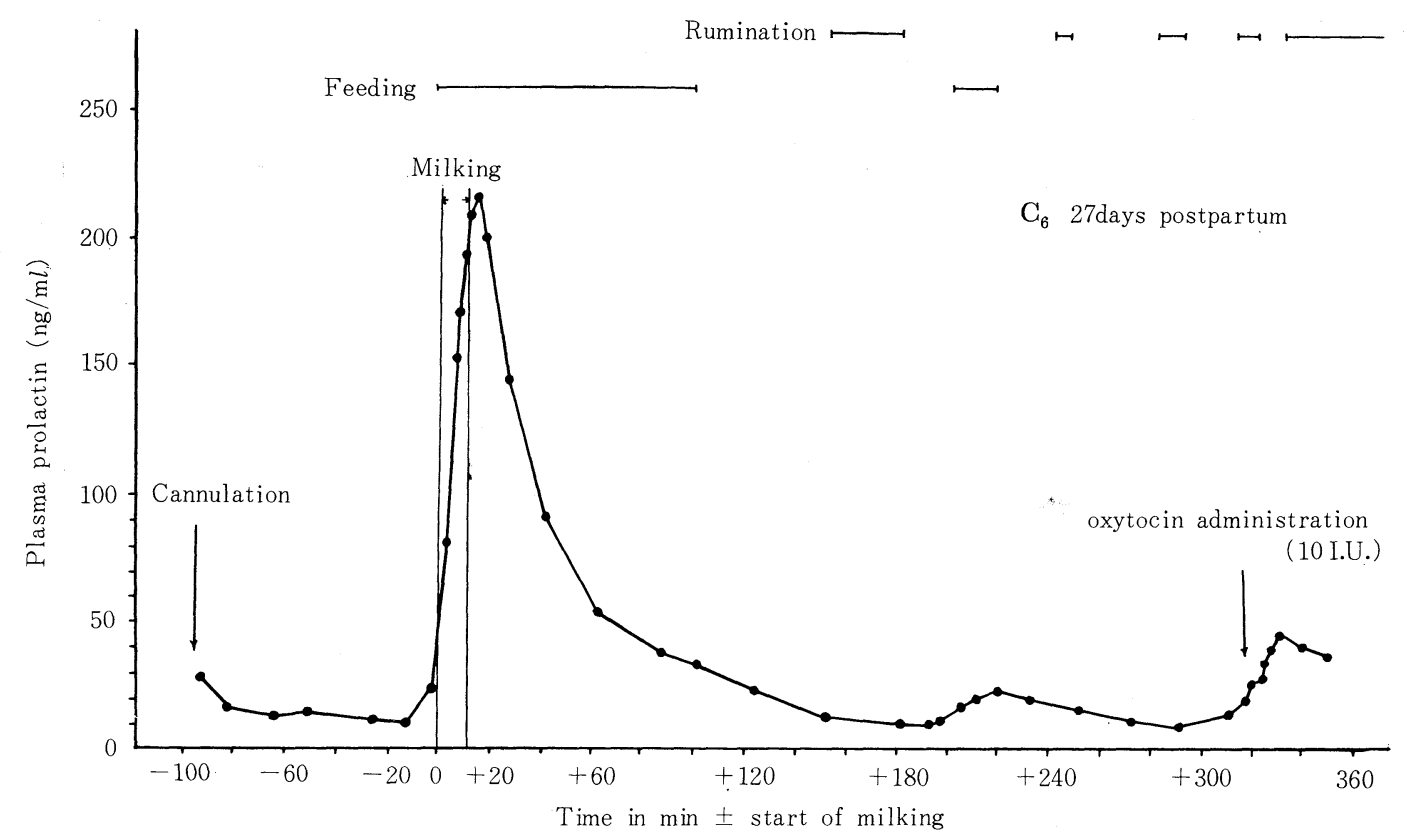

Fig. 1. Changes of plasma prolactin concentration by milking, feeding and oxytocin administration in a cow. 


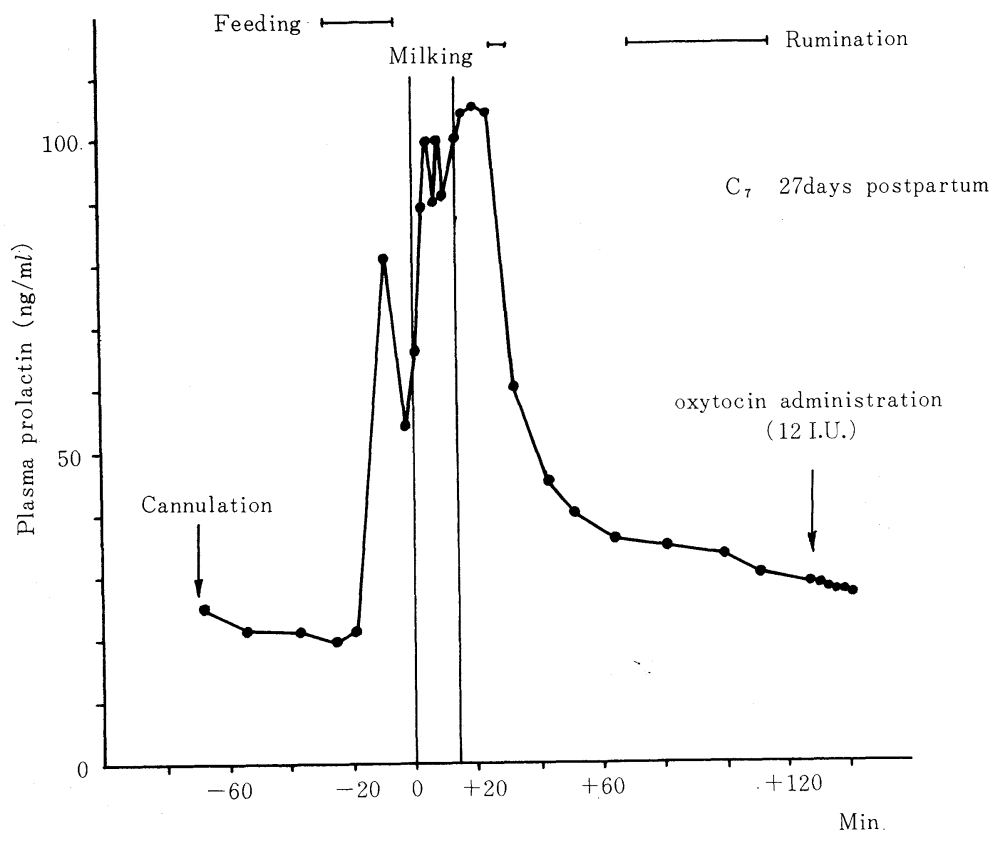

Fig. 2. Effects of feeding before milking and milking on plasma prolactin level in a cow.

milking were carried out in which serial blood samples were taken during the morning milking at different stages of lactation. Bovine plasma prolactin usually increased around the start of milking with the exception of 4 cases in which feed was given 10-30 min before milking (Figs. 1,2). Although feeding before milking induced a prompt increase of plasma prolactin concentration in these cases, the magnitude of prolactin release by milking itself exceeded the value obtained by feeding (Fig. 2). Milking without feeding caused the rapid increase of plasma prolactin levels as in the case of milking with feeding. In all cases, the plasma prolactin level reached a peak 4-20 min after the start of milking. However, the magnitude of prolactin release by milking was considerably influenced by the stage of lactation (Fig. 3). In the early stage of lactation, there was a conspicuous prolactin release by milking with more than 2 - to 24 -fold increase (depending upon initial pre-milking level). On the other hand, the peak levels in middle and late stages of lactation decreased marke dlyas compared with those in the early stages of lactation (Table 1, Fig. 4). The mean of the peak levels was highest $(189 \pm 34 \mathrm{ng} / \mathrm{ml}$, SE) for 27-42 days after calving, but it decreased to $14.4 \pm 4.4 \mathrm{ng} / \mathrm{m} l$ (SE) for 223-281 days postpartum. The maximum daily milk production was obtained in 3-8 weeks after calving. The peak of plasma prolactin released by milking was highest in the early stage of lactation and decreased thereafter with the advance of lactation (Fig. 4).

Although the mean value of the peak level obtained by milking in the pregnant and lactating cow was higher than that in the nonpregnant and lactating cow at the middle stage of lactation (102-143 days postpartum), the difference was not significant. The mean value of pre-milking time in the earlier stages of lactation (14-58 days postpartum) were higher than that in the later stages of lactation. Also the mean value of the lowest plasma prolactin level in the earlier stages of lactation was higher than that in the later stages of lactation. The lowest plasma prolactin levels in each experiment were usually obtained $2-3 \mathrm{hr}$ after milking. The data indicated that the value at 


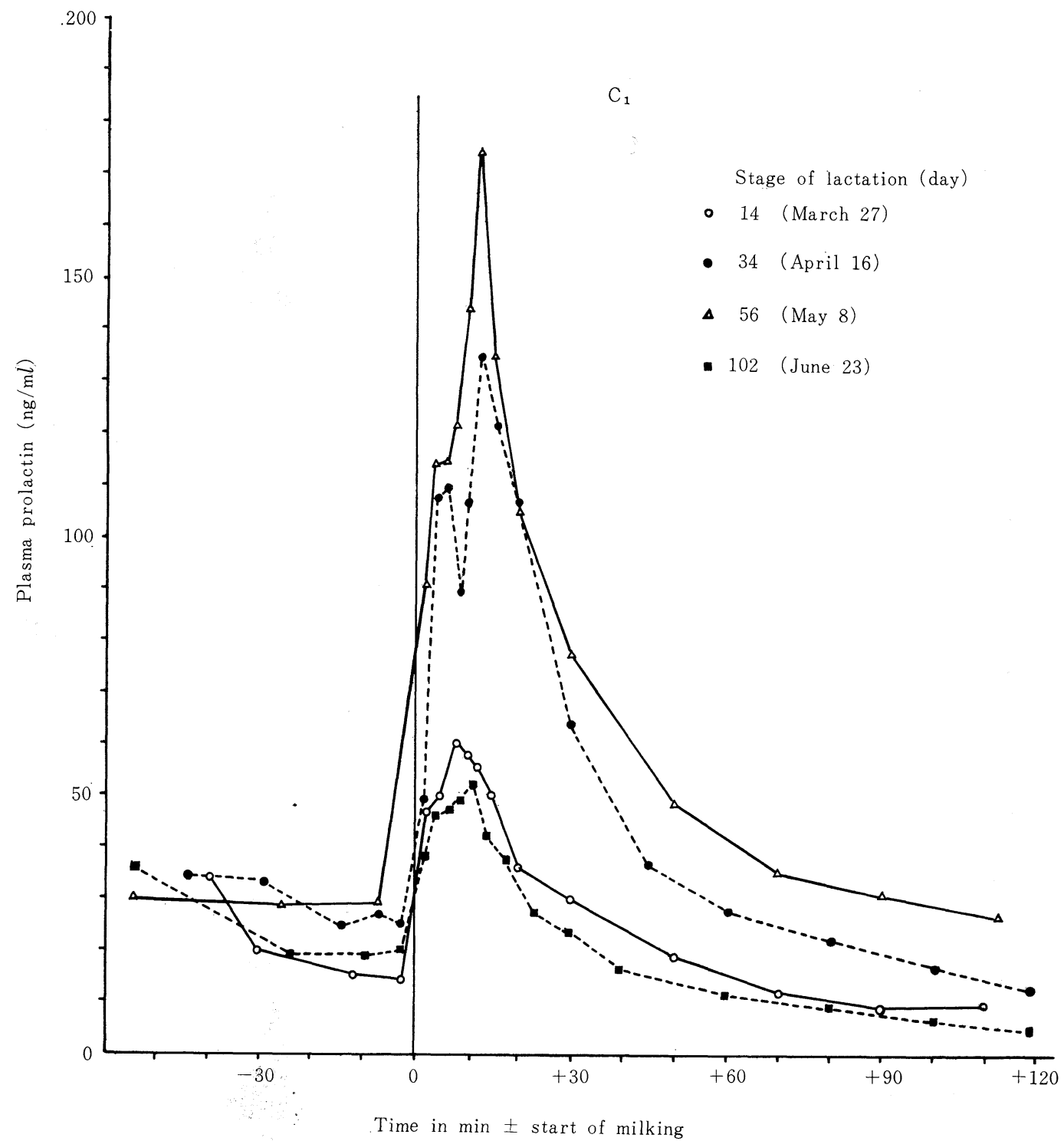

Fig. 3. Changes of the response of prolactin release by milking at different stages of lactation in a cow.

pre-milking time was more or less affected by the stressful stimuli associated with cannulation, and the lowest value obtained at the experiment was also affected by the magnitude of the prolactin release by milking.

Five Saanen goats at the mid-lactation stage were milked by hands without udder washing and feeding. The plasma prolactin level in the goat commenced to increase within 1-2 min after the start of milking (Fig. 5). Milking stimulus induced a more than $40-$ to 100 fold increase of plasma prolactin concentration above pre-milking within 5-10 min after the start of milking (Table 1). The peak plasma prolactin level obtained by the second milking stimulus applied for $2 \mathrm{~min}, 202 \mathrm{~min}$ after the 
Table 1. Changes of plasma prolactin level by milking in the lactating cow and goat

\begin{tabular}{|c|c|c|c|c|c|c|c|}
\hline Stage of lactation (day) & $14-18$ & $27-42$ & $\begin{array}{l}\text { Cow } \\
51-58\end{array}$ & $102-143$ & $104-138^{1)}$ & $223-281^{2)}$ & $\begin{array}{l}\text { Goat } \\
\quad 42-79\end{array}$ \\
\hline No. of animals & 5 & 6 & 5 & 4 & 4 & 4 & 5 \\
\hline $\begin{array}{l}\text { Plasma prolactin at pre- } \\
\text { milking time }(\mathrm{ng} / \mathrm{m} l)\end{array}$ & $22.2 \pm 3.9^{*}$ & $29 \pm 8.4$ & $43.2 \pm 9.2$ & $11 \pm 2.9$ & $6.5 \pm 1.2$ & $9.7 \pm 3$ & $20.2 \pm 6.4$ \\
\hline $\begin{array}{l}\text { Maximum plasma prolac- } \\
\text { tin after the start of milk- } \\
\text { ing }(\mathrm{ng} / \mathrm{ml})\end{array}$ & $143 \pm 61$ & $189 \pm 34$ & $151 \pm 39.8$ & $29.2 \pm 7.7$ & $7 \quad 39 \pm 3.3$ & $14 \pm 4.4$ & $1063.8 \pm 283.5$ \\
\hline $\begin{array}{l}\text { Lowest plasma prolactin } \\
\text { at the experiment }(\mathrm{ng} / \mathrm{m} l)\end{array}$ & $19 \pm 4.1$ & $22 \pm 9.6$ & $34.8 \pm 10.7$ & $7.3 \pm 0.9$ & $3.8 \pm 0.5$ & $4.8 \pm 0.2$ & $9.2 \pm 2.6$ \\
\hline $\begin{array}{l}\text { Time required to reach } \\
\text { maximum plasma prolac- } \\
\text { tin level after the start of } \\
\text { milking (min) }\end{array}$ & $9.2 * *$ & 14.1 & 12.0 & 13 & 13.3 & 5.5 & 8.2 \\
\hline $\begin{array}{l}\text { Duration of milking at the } \\
\text { experiment (min) }\end{array}$ & 9.4 & 11.1 & 10.0 & 11.8 & 10.8 & 6.8 & 4.8 \\
\hline $\begin{array}{l}\text { Milk yield at the experi- } \\
\text { ment (kg) }\end{array}$ & 12.9 & 16.2 & 15.1 & 12 & 7.9 & 9.3 & 1.6 \\
\hline Milk yield per day $(\mathrm{kg})$ & 28.2 & 29 & 26.7 & 21.4 & 15.9 & 16.5 & 1.6 \\
\hline
\end{tabular}

1) Pregnant, 1-2 months after conception.

2) Pregnant, 2-5 months after conception.

* Mean and standard error of the mean.

** Mean

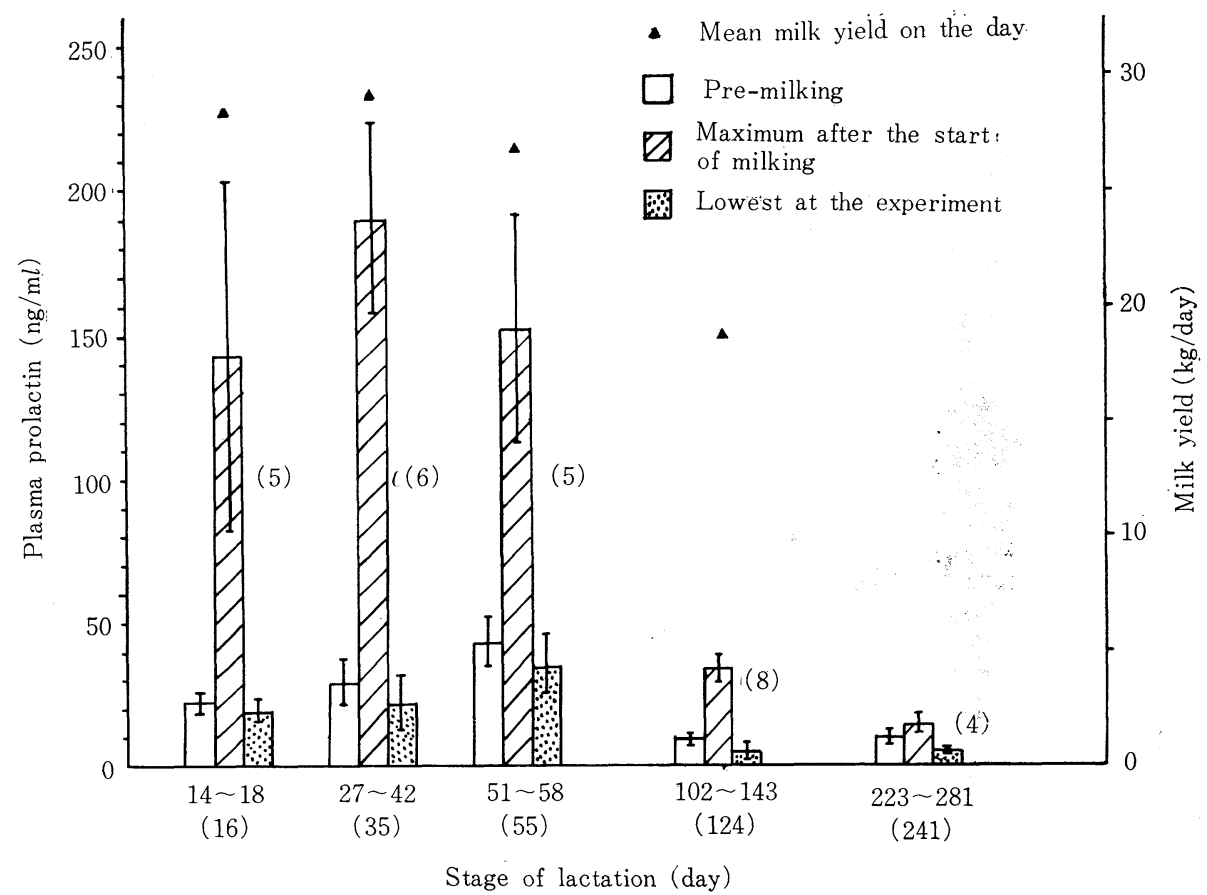

Fig. 4. Changes of the response of prolactin release by milking at different stages of lactation in cows. Vertical bars indicate the standard error of the mean. 


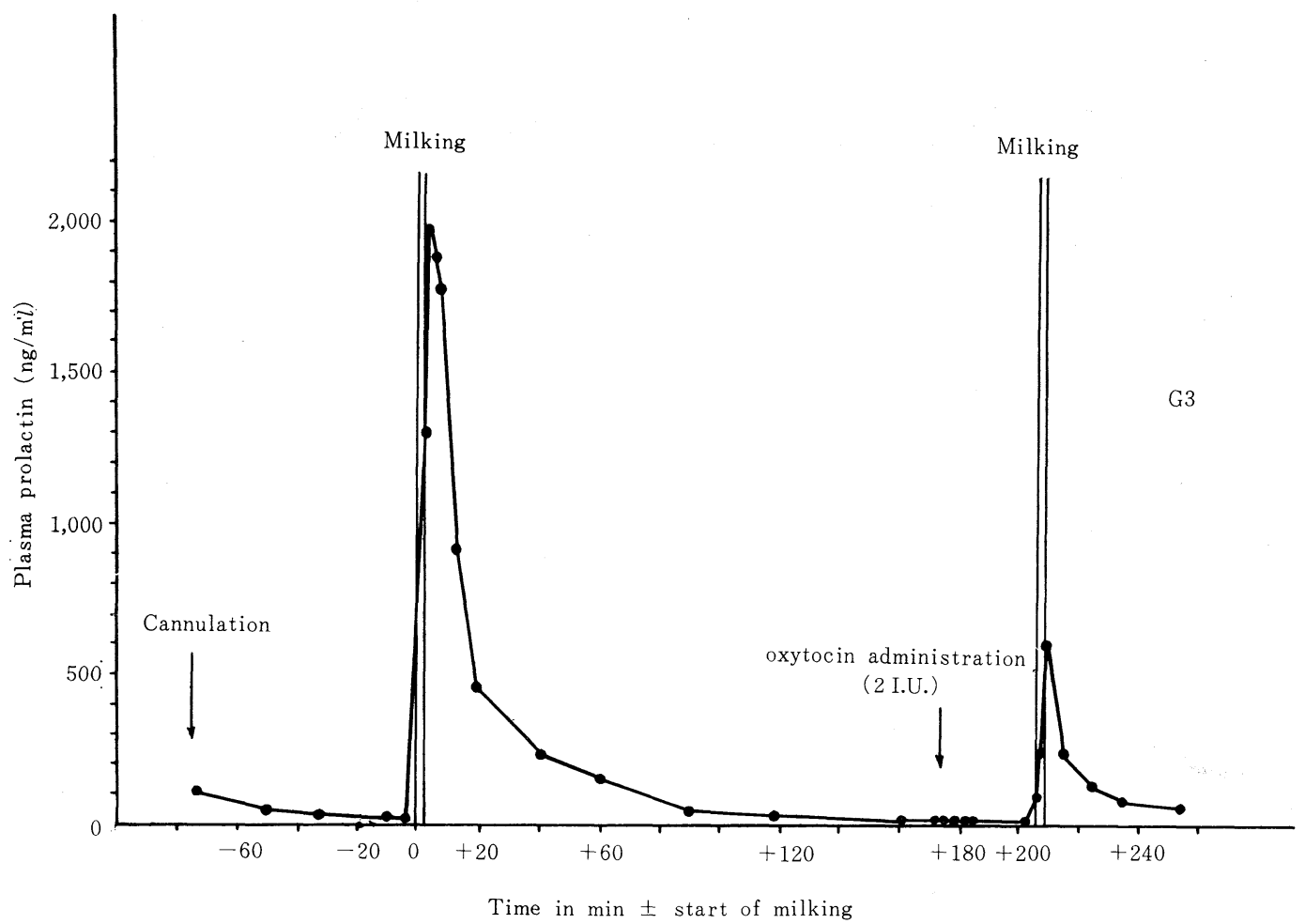

Fig. 5. Changes of plasma prolactin concentration by milking in a goat.

first milking (for $2 \mathrm{~min}$ ) was one-fourth of the value obtained by the first milking (Fig. 5).

\section{Effect of feeding in the lactating cow}

In the earlier part of this paper, we described a prompt rise of bovine plasma prolactin level by the feeding of concentrate before milking (Fig. 2). Further study was undertaken on the effect of feeding. Two to $3 \mathrm{hr}$ after milking, concentrate was given to the cows for 15-25 min. The elevation of plasma prolactin level was observed in 3 of 6 experiments at the early stage of lactation (Fig. 1) and 8 of 9 experiments at the middle stage of lactation within 5 min after the start of feeding (Fig. 6).

\section{Response to mimic-milking in heifers and virgin goats}

In order to determine whether mimic- or sham- milking in non-lactating animals can also cause prolactin release or not, an experiment was carried out. The teats were pulled and the udder was massaged by hands for 5 min in heifers and virgin goats. The plasma prolactin level commenced to increase within 2 min after the start of mimic-milking in 2 of 3 heifers and in all of 3 non- lactating cows, although there was no milk flow (Table 2). The value reached a peak 5-15 min after the commencement of stimulation. While mimic-milking induced a rapid prolactin release, feeding concentrate for $10 \mathrm{~min} 2 \mathrm{hr}$ before mimic-milking ( $2 \mathrm{hr}$ after cannulation) did not show appreciable changes of the plasma prolactin level in 2 experimental animals (Table 2). An acute rise of plasma prolactin concentration by mimic-milking was also observed in 1 of 2 virgin goats. Six min after the start of mimic-milking, the value rose to $260 \mathrm{ng} / \mathrm{m} l$ from $125 \mathrm{ng} / \mathrm{m} l$ of pre-stimulation. 


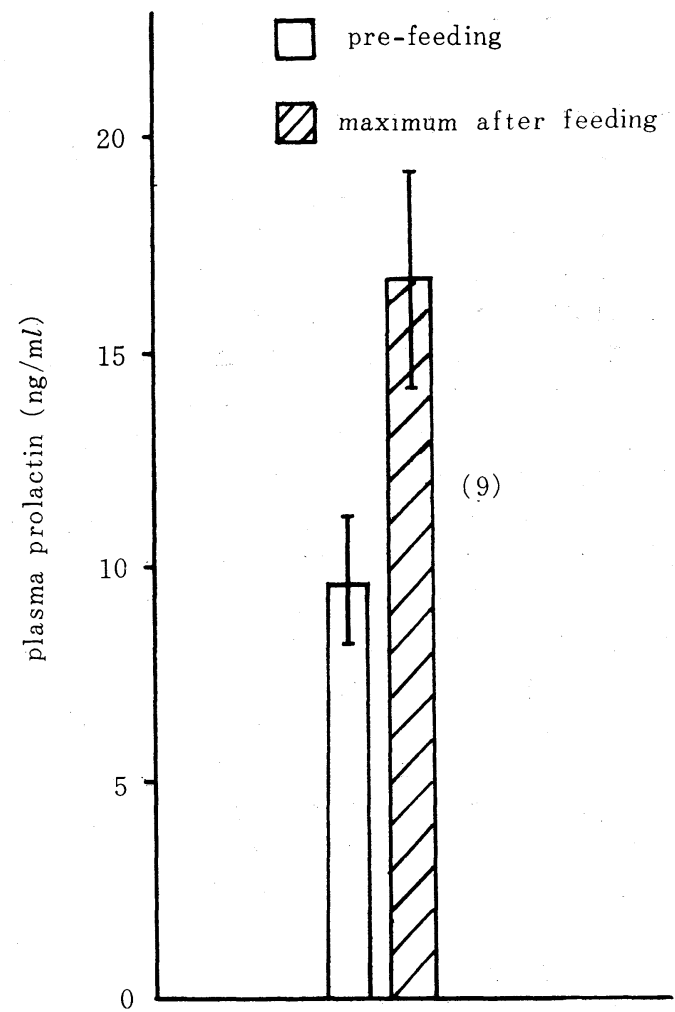

Fig. 6. Effect of feeding 2-3 hr after milking on the bovine prolactin level in plasma at the middle stage of lactation. Vertical bars indicate the standard error of the mean.

\section{Effect of needle puncture and other stimuli}

Prolactin concentration in plasma obtained within 3 min after cannulation with needle puncture was higher than that within $30-60 \mathrm{~min}$ after the treatment in 27 of 34 lactating and non-lactating cows (Fig. 1). A similar change of plasma prolactin level after cannulation was obtained in 5 of 7 lactating and virgin goats (Fig. 5). An additional subcutaneous needle puncture also induced a rapid increase of plasma prolactin concentration in 2 of 4 lactating cows and in 2 of 3 heifers (1.7-2.8 fold increase in positive cases). These results indicate that the stressful stimuli associated with needle puncture (pain, forced restraint and emotional disturbance, etc.) could cause the rapid prolactin release in the cattle and the goat. On the other hand, no significant in-
Table 2. Changes of plasma prolactin level by mimicmilking and feeding in the heifers

\begin{tabular}{lcc}
\hline & Mimic-milking & Feeding \\
\hline $\begin{array}{l}\text { No. of animals } \\
\text { Plasma prolactin at } \\
\text { pre-stimulus (ng/m } l \text { ) }\end{array}$ & $14.2 \pm 4.2^{*}$ & $7 * *$ \\
$\begin{array}{l}\text { Maximum plasma pro- } \\
\text { lactin after the start of } \\
\text { stimulus (ng/m } l \text { ) }\end{array}$ & $39.7 \pm 10.2$ & 6.5 \\
$\begin{array}{l}\text { Lowest plasma prolactin } \\
\text { at the experiment(ng/m } l \text { ) }\end{array}$ & $7 \pm 2$ & 5.5 \\
$\begin{array}{l}\text { Duration of stimulus } \\
\text { (min) }\end{array}$ & 5 & 10 \\
\end{tabular}

* Mean and standard error of the mean

** Mean

crease of plasma prolactin level was detected by continuous bleeding from catheter for at least $4 \mathrm{~min}(50-60 \mathrm{ml})$ in 3 lactating cows.

The administration of oxytocin (Atonin-O, Teikokuzoki Co., Ltd., 10-15 I.U.) through venous catheter $2-5 \mathrm{hr}$ after milking induced a moderate rise of plasma prolactin level in 3 of 4 cows at the early stage of lactation (Fig. 1). In the 2 lactating goats, the administration of oxytocin (2 I.U.) through venous catheter showed no change of plasma prolactin concentration (Fig. 5). Rumination did not cause any concomitant change of plasma prolactin level in the cow and the goat.

\section{Discussion}

The results of the foregoing experiment demonstrate that a variety of stimuli including milking, mimic-milking, feeding and stressful stimuli can induce an acute and relatively short-lived release of prolactin in the cattle and the goat. The rapidness of the prolactin release suggests that the reaction may be elevated by the activation of the sensory nerve-hypothalamus-anterior pituitary reflex. Although a variety of non-specific stimuli could induce a rise in plasma prolactin con- 
centration, milking was the most powerful of all the stimuli from the acute prolactin release from the anterior pituitary in the cow and the goat. The plasma prolactin levels reached a peak 4-20 min after the start of milking and decreased rapidly thereafter. In most cases, plasma prolactin levels at premilking and 2-3 hr post-milking were considerably low as compared with the peak value induced by milking. In our previous study with lactating cows, the mean prolactin level in plasma obtained in the inter-milking period (6-7 hr after milking) was measured between 16 and $29 \mathrm{ng} / \mathrm{ml}$ (Johke et al., 1971). The above findings indicate that the plasma prolactin levels in the lactating animals are not always maintained at high levels. The "basal level" (values during the inter-milking period in rest state) of prolactin in plasma may be less than $30 \mathrm{ng} / \mathrm{ml}$ in the majority of cows at the early stage of lactation. However, an acute and conspicuous rise of plasma prolactin level occurs reflexively with milking stimulus.

The response of prolactin release by milking varied considerably at different stages of lactation even in the same cow. The peak of plasma prolactin released was highest in the early stage and decreased thereafter with the advance of lactation. The reason for the reduction in responsiveness to milking stimulus after the middle stage of lactation is not clear at present. One of the possibilities is that the rate of prolactin synthesis decreases with the advance of lactation. This may result in the decrease of pituitary prolactin which is releaseable with milking stimulus. Another possibility is a gradual reduction in the sensitivity of reflexive prolactin release to the stimulus with the advance of lactation. In either case, it is assumed that the mammary gland after the middle stage of lactation may need much less prolactin to continue the milk secretion than in the early stage.

It is noteworthy that mimic- or sham-milking could evoke a rapid prolactin release even in heifers and virgin goats, though there was no milk flow. The results show that the direct manipulation of the udder is a powerful stimulus to induce an acute prolactin release in non-lactating animals as in the case of lactating animals. Cowie et al. (1968) demonstrated that the continuous application of milking stimulus twice daily in the ovariectomized virgin goats induced the initiation of lactation and maintained copious milk flow.

On the other hand, experiments by Denamur and Martinet (1960) and Linzell (1963) in goats and sheeps have demonstrated that full milk secretion could be maintained after severing the nervous connections between the udder and central nervous system. Yokoyama and Ōta (1965) also reported that no decrease in milk yield was observed in the experiment of milking under cyclopropane anaesthesia for 2 weeks in the lactating goat. To explain the secretion of prolactin and other lactogenic hormones from adenohypophysis in these particular cases, several possibilities have been proposed (see Meites, 1966 and Tindal, 1967 for reviews). However, the true mechanism is not clear, since prolactin and other lactogenic hormones were not determind in these experiments.

Unexpectedly, the study of circulating prolactin concentration in lactating cows revealed that feeding is also one of the stimulators of an acute prolactin release. The response by feeding concentrate in the lactating cow is assumed to be one of the conditioned reflex associated with milking routine as in the case of oxytocin reported by Cleverley and Folley (1970).

Recently, Bryant and Greenwood (1968) reported that the intravenous injection of oxytocin caused a transient rise of plasma prolactin level in a lactating goat. In the limited data, however, the administration of oxytocin through venous catheter did not induce the elevation of plasma prolactin in 2 goats. On the other hand, a rise of plasma prolactin was observed by oxytocin administration in 3 of 4 cows, although there was no appreciable rise of plasma prolactin after the infusion of heparinized saline $(3-4 \mathrm{~m} l)$ alone. 
Further studies will be needed to elucidate the specific effect of oxytocin upon prolactin release in the cow or the goat.

Non-specific stimulus such as stress associated with needle puncture can also stimulate a release of prolactin in the lactating and the non-lactating animals. It was also suggested that stress of handling and venipuncture might elevate the plasma prolactin level in the sheep or the goat (Bryant et al., 1968). An acute depletion of prolactin content in the pituitary of rat after laparotomy with bleeding or cervical stunning followed by decapitation was reported by Grosvenor et al. (1965). Several noxious stimuli can induce a rapid and short-lived increase of simian growth hormone concentration in plasma (Meyer and Knobil, 1967). The physiological "utility" of the acute increase in plasma prolactin concentration in response to non-specific stimuli is not clear as in the case of growth hormone.

In sharp contrast to other pituitary hormones, the regulation of the secretion of pituitary prolactin in mammal appears to be mediated by prolactin inhibiting factor (PIF) in the hypothalamus (see Everett, 1969 for review). If the hypothalamic PIF excercises chronically an inhibitory influence on the secretion of bovine and caprine prolactin, the results of the present study suggest that inhibitory action of PIF on the release of pituitary prolactin may be readily suppressed in response to several stimuli in the lactating and the non-lactating animals. The magnitude of the release of prolactin may be determined by both the amount of stored prolactin in pituitary and the quality and quantity of the stimulus given at the time.

\section{Acknowledgements}

The author wishes to thank the Endocrinology
Study Section, National Institutes of Health, U.S.A. for generous supplies of bovine and ovine prolactin. The author is indebted to Professor Y. Suzuki, Faculty of Agriculture, University of Tokyo, for many helpful discussions and suggestions, and Mr. H. Fuse for his valuable assistance during this work.

\section{References}

Bryant, G. D. and F. C. Greenwood (1968). Biochem. J. 109, 831.

Bryant, G. D., R. M. Connan and F. C. Greenwood (1968). J. Endocrinol. 41, 613.

Cleverley, J. D. and S. J. Folley (1970). Ibid. 46, 347.

Cowie, A. T., G. S. Knaggs, J. S. Tindal and A. Turvey (1968). Ibid. 40, 243.

Denamur, R. and J. Martinet (1960). Nature, Lond. 185, 252.

Everett, J. W. (1969). Ann. Rev. Physiol. 31, 383.

Grosvenor, C. E., S. M. MacCann and R. Nallar (1965). Endocrinology 76, 883.

Johke, T. (1969 a). Endocrinol. Japon. 16, 179. Johke, T. (1969 b). Ibid. 16, 581.

Johke, T., H. Fuse and M. Ōshima (1969). Jap. J. Zootech. Sci. 39, Suppl. 117. (abstract in Japanese).

Johke, T., H. Fuse and M. Ōshima (1971). Ibid. in press.

Linzell, J. L. (1963). Q. J. exp. Physiol. 48, 34.

Meites, J. Neuroendocrinology, Vol. 1 (edited by L. Martini and W. F. Ganong). Academic Press, New York, P. 539. (1966).

Meyer, V. and E. Knobil (1967). Endocrinology 80, 163.

Tindal, J. S. Reproduction in the Female Mammal, (edited by G. E. Lamming and E. C. Amoroso). Butterworths, London, P. 79. (1967).

Yokoyama, A. and K. Ota (1965). J. Endocrinol. 33, 341. 